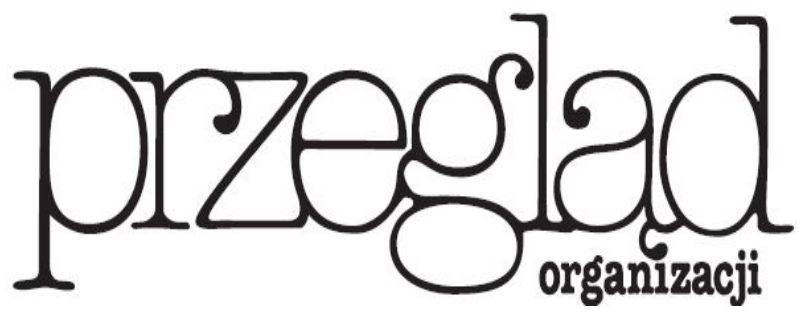

Miesięcznik TNOiK

Założył Karol Adamiecki w 1926 r.

\title{
MODEL ARCHITEKTURY PROCESÓW WE WSPÓŁCZESNYCH PRZEDSIĘBIORSTWACH
}

https://doi.org/10.33141/po.2019.02.02

\section{Agnieszka Bitkowska}

\section{Wprowadzenie}

D ynamiczne zmiany $\mathrm{w}$ otoczeniu przedsiębiorstw obejmują umiędzynarodowienie przedsiębiorstw, postępującą globalizację, digitalizację, rozwój technologii mobilnych, wykorzystanie mediów społecznościowych, rozwój nowoczesnych rozwiązań technologicznych czy koncepcji Internetu Rzeczy (Jelonek, Turek, 2015; Ciesielska-Maciągowska, Frąszczak, 2017). Zmiany w obszarze technologii informacyjnych umożliwiają rozszerzenie zakresu oferowanych produktów i usług oraz łatwiejszy i szybszy dostęp do informacji na ich temat. Ponadto postępująca globalizacja, gospodarka oparta na wiedzy, rewolucja technologiczna, digitalizacja oraz rozwój handlu elektronicznego determinują funkcjonowanie współczesnych przedsiębiorstw. Istotną rolę odgrywa zarządzanie procesowe (Nowosielski 2017a; 2018; Trocki 2012), łączące zarówno aspekty strategiczne, jak i operacyjne. Fundament zarządzania procesowego tworzą następujące elementy: model architektury procesów, przejrzystość procesów, mechanizmy monitoringu i mechanizmy doskonalenia (Biazzo, Bernardi, 2003; Rummler, Brache, 2000). Związek strategii organizacji i zachodzących w niej procesów wykazuje również A. Kaleta (2000), według którego wyniki procesów realizowanych w organizacji powinny być oceniane przede wszystkim w odniesieniu do przyjętej misji i powiązanych z nią celów strategicznych. Koncentracja na procesach zachodzących $\mathrm{w}$ organizacji jest więc koniecznym warunkiem realizacji założeń strategicznych. R. Kaplan i D. Norton (2008) podkreślają, że za-
Przegląd Organizacji, Nr 2 (949), 2019, ss. 14-21 www.przegladorganizacji.pl CTowarzystwo Naukowe Organizacji i Kierownictwa (TNOiK) łożenia strategiczne organizacji powinny być powiązane $\mathrm{z}$ funkcjonowaniem systemu procesów, bowiem $\mathrm{w}$ takiej sytuacji możliwe jest odpowiednie przełożenie jej na działania poprzez zastosowanie Strategicznej Karty Wyników.

Coraz więcej przedsiębiorstw dostrzega konieczność implementacji modelu architektury procesów, który umożliwia powiązanie płaszczyzny strategicznej z operacyjną. Pojawia się potrzeba analizy modelu biznesu uwzględniającego relację pomiędzy poszczególnymi procesami wewnątrz organizacji, jak również z otoczeniem zewnętrznym. Brak w polskiej literaturze publikacji poruszających zagadnienia architektury procesów wskazuje na konieczność podjęcia rozważań zarówno w warstwie teoretycznej, jak i praktycznej. Celem artykułu jest ukazanie użyteczności tworzenia modelu architektury procesów we współczesnych przedsiębiorstwach. W artykule wykorzystano następujące metody i techniki badawcze: analizę literatury przedmiotu oraz studium przypadku przedsiębiorstwa telekomunikacyjnego funkcjonującego w Polsce. Przedstawione w artykule rozważania mają zarówno walor poznawczy, jak i aplikacyjny.

\section{Istota modelu architektury procesów}

$M$ odel biznesu to narzędzie zawierające pewien zestaw elementów i relacji między nimi, przedstawiający pomysł na biznes w sposób schematyczny (Brzóska, 2009, s. 6). K. Obłój definiuje model biznesu jako po- 
łączenie koncepcji strategicznej przedsiębiorstwa i technologii jej realizacji, rozumianej jako budowa łańcucha wartości pozwalającego na skuteczną eksploatację oraz odnowę zasobów i umiejętności (Obłój, 2002). Jest to możliwe $\mathrm{z}$ wykorzystaniem takich procesów zarządzania, które uwzględniają oddziaływanie otoczenia konkurencyjnego. Strategia bowiem wyraża sposób działań przedsiębiorstwa w stosunku do zmieniających się warunków otoczenia i jego wnętrza (Brzóska, 2009; Gołembiowski i in., 2008, s. 57). Wdrażanie strategii powinno budować taki łańcuch wartości, który nie tylko skutecznie eksploatuje zasoby i umiejętności przedsiębiorstwa, ale także umożliwia ich odnawianie. Aspekt unikalności konfiguracji elementów, stanowiących model biznesu jest bardzo istotny, stanowi o budowaniu konkurencyjności przedsiebiorstwa. Konfiguracja taka, składająca się z celów organizacji, strategii, procesów, technologii oraz struktury, kreuje wartość dla klientów, umożliwiając w ten sposób przedsiębiorstwu skuteczne konkurowanie na określonym rynku (Ehiraj i in., 2000). Kreowanie wartości opiera się na składowych elementach, do których można zaliczyć: przewagę konkurencyjną, zasoby i umiejętności oraz łańcuch wartości.

Model architektury procesów (procesowy model organizacji) można zdefiniować jako uporządkowany zestaw zachodzących procesów biznesowych, określający wytyczne oraz wewnętrzne relacje, jak również sposób ich przebiegu (Aredes, Dallavalle de Pádua, 2014). Model architektury procesów stanowi strukturę zarządzania procesowego łączącą strategię z działaniami operacyjnymi. Architektura procesów oznacza pierwszy etap zorientowania przedsiębiorstwa na ujęcie procesowe (Burlton, 2001). Ponadto stanowi hierarchiczny model prezentujący działania organizacji z perspektywy postrzegania zachodzących procesów (Pritchard, Armistead, 1999). Model architektury procesów może służyć jako narzędzie do projektowania struktury procesów oraz do zdefiniowania zakresów i granic procesów.

S. Cyfert $(2006$, s. 20) wskazuje, iż model architektury procesów ${ }^{1}$ odzwierciedla wewnętrzną strukturę organizacji procesowej, opisuje procesy oraz logikę powiązań pomiędzy nimi na poszczególnych poziomach, co stanowi odpowiednik struktury organizacyjnej w organizacjach funkcjonalnych. Jak podkreśla S. Nowosielski, procesy gospodarcze są naturalnymi elementami każdej organizacji, istnieją niezależnie od woli ludzi, a zarządzanie nimi (i ich doskonalenie) powinno być obowiązkiem kierownictwa organizacji (Nowosielski, 2018, s. 111). Zdefiniowanie architektury procesów jest warunkiem koniecznym dla każdej organizacji zorientowanej procesowo, przy czym należy uwzględnić następujące założenia:

- procesy, które mają zostać przeprojektowane lub nowo opracowane, spełniają założenia strategiczne,

- procesy są dostosowane do potrzeb przedsiębiorstwa i potrzeb klientów oraz otoczenia,

- wszystkie informacje dotyczące procesów są monitorowane i raportowane najwyższemu kierownictwu w przejrzysty sposób.
Model architektury procesów powstaje poprzez identyfikację i planowanie procesów w przedsiębiorstwie $\mathrm{w}$ wyniku realizacji podejścia projektowego $\mathrm{z}$ uwzględnieniem założeń strategicznych. Interesujący model architektury procesów zaprezentował R. Burlton, który uwzględnił następujące elementy składowe: strategię, politykę i regulacje prawne, strukturę organizacyjną, infrastrukturę oraz technologię i kapitał ludzki (rys. 1). Prezentowane podejście zawiera elementy wynikające $\mathrm{z}$ funkcjonowania przedsiębiorstwa $\mathrm{w}$ określonym otoczeniu zewnętrznym (m.in. wymogi prawne, potrzeby i oczekiwania klientów) oraz wymaga zdefiniowania czynników wewnętrznych (m.in. struktura organizacyjna, kapitał ludzki). W modelu architektury procesów należy uwzględnić budowanie relacji $\mathrm{z}$ interesariuszami zewnętrznymi i wewnętrznymi - klientami, partnerami i konkurentami. Wynika stąd konieczność dostrzegania elementów łączenia przyjętej strategii przedsiębiorstwa z jej praktycznym wdrażaniem, a więc operacyjną działalnością realizowaną poprzez innowacyjne inicjatywy i projekty. Tworząc model architektury procesów, należy także uwzględnić przesłanki jej tworzenia zaprezentowane w tabeli 1 .

Tabela 1. Wymagania tworzenia architektury procesów

\begin{tabular}{|c|c|}
\hline $\begin{array}{l}\text { Wymagania } \\
\text { dotyczące } \\
\text { architektury } \\
\text { procesów }\end{array}$ & $\begin{array}{l}\text { - procesy powinny być powiązane ze strategią } \\
\text { i celami organizacji } \\
\text { - powinien istnieć zbiór zasad, reguł zarządzania } \\
\text { procesowego oraz modeli procesów } \\
\text { - powinny być wykorzystywane narzędzia } \\
\text { do projektowania i realizacji procesów } \\
\text { w organizacji } \\
\text { - modele procesów powinny być czytelne, łatwe } \\
\text { do zrozumienia i stosowania przez wszystkich } \\
\text { pracowników } \\
\text { - architektura procesów musi być dynamiczna, } \\
\text { zmienna w odniesieniu do zachodzących } \\
\text { przemian w otoczeniu }\end{array}$ \\
\hline
\end{tabular}

Źródło: opracowanie na podstawie: Jeston, Nelis, 2014

\section{Uwarunkowania tworzenia modelu architektury procesów we współczesnych przedsiębiorstwach}

onfiguracja architektury procesów opisywana jest za pomocą głębokości procesów (poziomu procesów), co charakteryzuje układ procesów na pierwszym poziomie szczegółowości (Cyfert, 2006, s. 28). Budowa architektury procesów powinna uwzględniać koncepcję jednowymiarowego łańcucha wartości dodanej, zaproponowaną przez M. Portera, prezentującą powiązania przedsiębiorstwa $\mathrm{z}$ otoczeniem. Wiele przedsiębiorstw, tworząc architekturę procesów, wykorzystuje różne modele referencyjne (np. APQC). Przedsiębiorstwa mają możliwość wykorzystania tzw. architektury referencyjnej, które mają charakter znormalizowany, zapewniają najlepsze praktyki branżowe oraz wytyczne do budowy dla poszczególnych sektorów (w sektorze telekomunikacji - eTOM, TAM, SID) (Paradkar, 2018). 


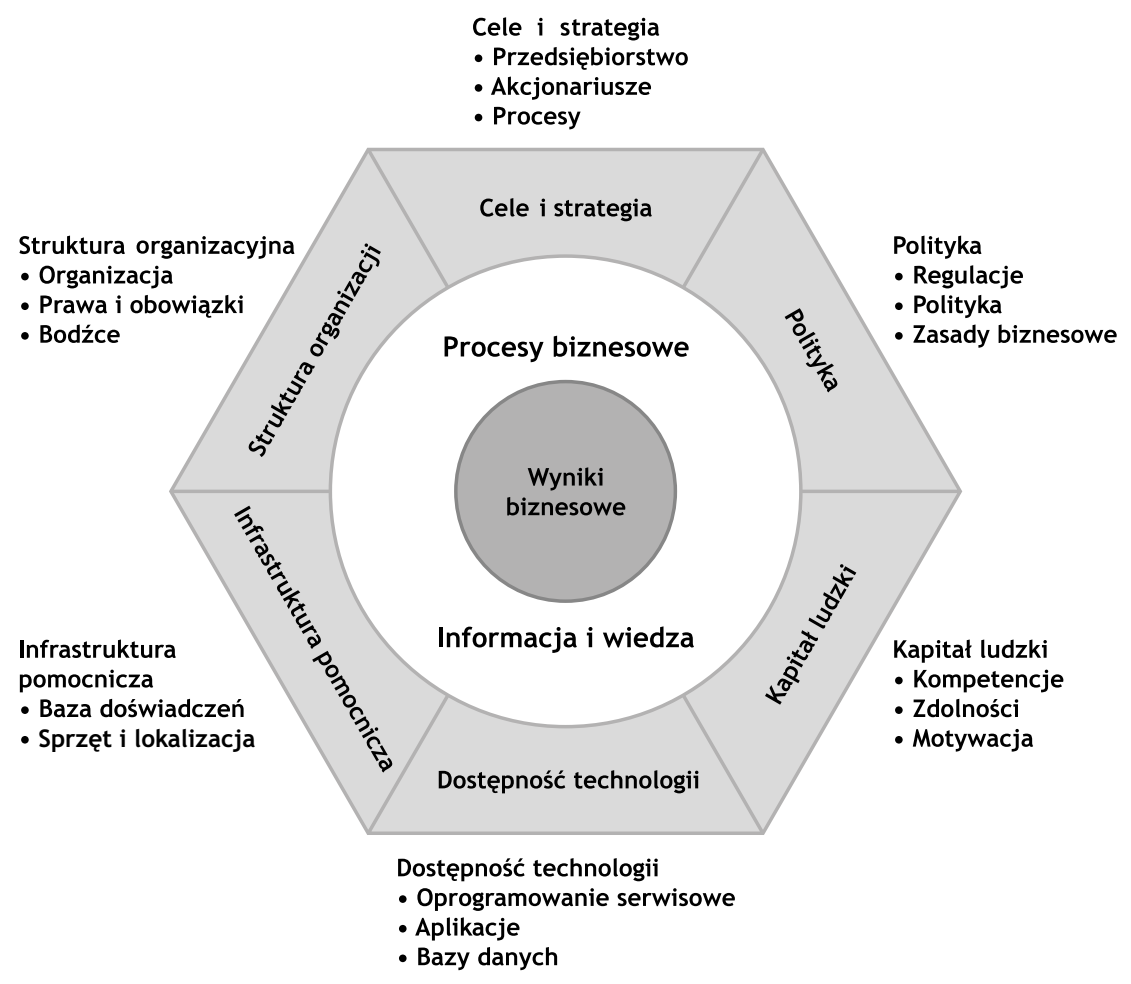

Rys. 1. Model architektury procesów w przedsiębiorstwie Źródto: Burlton, 2015

Hierarchiczną strukturę wielopoziomową można zdefiniować jako makroprocesy, procesy, podprocesy, działania (Smart i in., 2009) lub jako hierarchię procesów rozpoczynających się od poziomu 0 , który reprezentuje łańcuch wartości, przechodząc na poziom 1, gdzie każdy element łańcucha wartości jest podzielony na zestaw procesów, które $\mathrm{z}$ kolei można podzielić na inne podprocesy, na poziom 2 itd. (Harmon, 2010). Model architektury procesów powinien służyć zewnętrznym i wewnętrznym interesariuszom i być zaprojektowany we właściwy sposób (tab. 2).

Tabela 2. Projektowanie modelu architektury procesów w przedsiębiorstwach

\begin{tabular}{|l|l|}
\hline $\begin{array}{l}\text { Projektując } \\
\text { architekturę }\end{array}$ & - $\begin{array}{l}\text { powiązanie procesów z celami strategicznymi } \\
\text { i ich miernikami }\end{array}$ \\
procesów, & - $\begin{array}{l}\text { powiązanie procesów z misją, wizją, } \\
\text { kierunkami i celami strategicznymi } \\
\text { należy }\end{array}$ \\
$\begin{array}{l}\text { uwzględnić } \\
\text { następujące } \\
\text { zagadnienia }\end{array}$ & $\begin{array}{l}\text { segmentację klientów i strategicznych } \\
\text { interesariuszy }\end{array}$ \\
& - $\begin{array}{l}\text { hierarchię procesów, } \\
\text { sposób implementacji architektury procesów }\end{array}$ \\
\hline
\end{tabular}

Źródło: opracowanie własne

Model architektury pomaga również $\mathrm{w}$ identyfikacji potencjalnych obszarów ryzyka, które $\mathrm{w}$ trakcie realizacji projektów mogą wpłynąć niekorzystnie na relacje $\mathrm{z}$ interesariuszami procesów (Dębska-Gill, Woźniakowska, 2013). Tworzenie architektury procesów biznesowych należy do istotnych, a zarazem skomplikowanych zagadnień z zakresu zarządzania procesowego. W trakcie trwania prac pojawiają się dyskusyjne kwestie dotyczące zasadności wybranych procesów, poziomów architektury (struktury hierarchii pro- cesów), sposobu komunikowania się i wzajemnych relacji pomiędzy procesami oraz przydzielonymi zasobami.

W praktyce przedsiębiorstwa wykorzystują architektury referencyjne (Paradkar, 2018), które zapewniają ramy odniesienia dla domeny lub wybranego sektora, w którym funkcjonuje przedsiębiorstwo. Modele referencyjne lub architektury zapewniają wspólny słownik, zdefiniowane projekty oraz najlepsze praktyki branżowe. Zazwyczaj architektura referencyjna obejmuje zasady, wzorce, bloki i standardy ${ }^{2}$. Większość z tych architektur referencyjnych obejmuje wspólne bloki biznesowe, możliwości biznesowe i procesy biznesowe dla określonej domeny pionowej. Mogą one obejmować wspólne modele danych, standardy komunikacji, a przede wszystkim wszelkie zasoby.

Jak podkreśla S. Cyfert, zastosowanie modelu zapewnia poprzez określenie szczegółowych charakterystyk produktów i grup docelowych klientów właściwe przeprowadzenie podziału procesów na podstawowe, pomocnicze i zarządcze oraz prawidłowe zdefiniowanie granic procesów zarówno $\mathrm{w}$ odniesieniu do poziomu makro (granice organizacja - otoczenie), jak i mikro (granice pomiędzy poszczególnymi procesami wewnątrz organizacji) (Cyfert, 2011, s. 440). S. Nowosielski wskazuje, iż w odniesieniu do procesów gospodarczych wykorzystuje się projekty wdrażania założeń (modyfikacji) strategii do modelu procesowego przedsiębiorstwa (Nowosielski, 2017b). Wymagane jest zdefiniowanie określonych zasad i reguł postępowania realizacji projektu.

S. Cyfert wskazuje na metodę strategicznego doskonalenia architektury procesów, która nakierowana jest na integrację strategii rozwoju i architektury procesów, zakłada konieczność realizacji następujących etapów: identyfikacji procesów, opracowania strategii rozwoju, budowy macierzy 


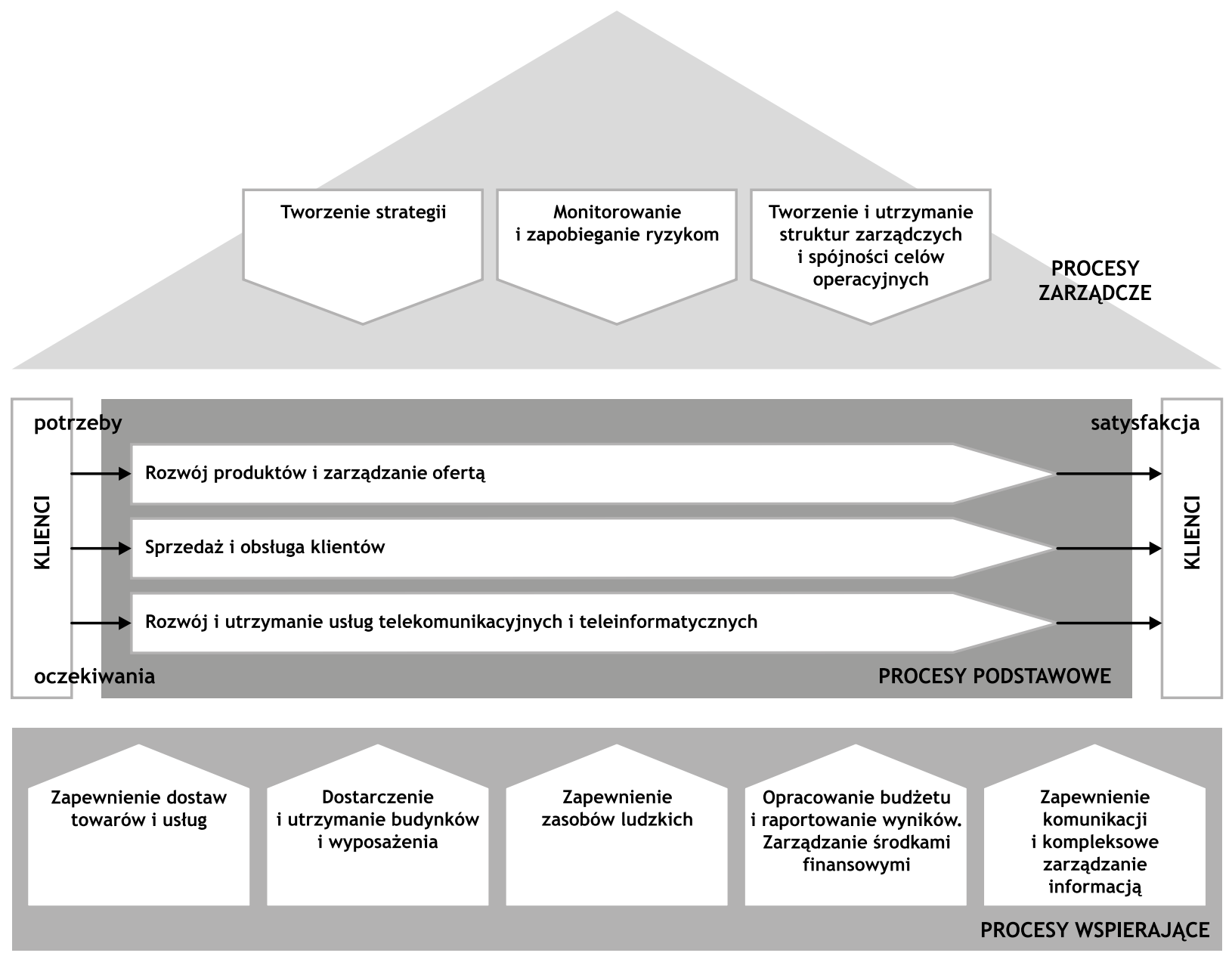

Rys. 2. Architektura procesów przedsiębiorstwa telekomunikacyjnego (poziom 1) w latach 2004-2009

Źródto: Pomykata, 2016

spójności, rekonstrukcji architektury procesów i przeprojektowania struktury organizacyjnej, zaprojektowania systemu pomiaru procesów (Cyfert, 2006, s. 186). W odniesieniu do każdego z tych etapów można wykorzystać szczegółową metodykę postępowania nakierowaną na integrację architektury procesów z zakładaną strategią rozwoju.

Badania realizowane cyklicznie na świecie wskazują, iż przedsiębiorstwa podejmują działania związane $\mathrm{z}$ doskonaleniem architektury procesów. Blisko 39\% przedsiębiorstw w 2017 roku, 43\% w 2015, 31\% w 2013 wskazało na rozwój architektury procesów z zakresie realizowanych projektów (Harmon, 2018). Jest to jeden $z$ najistotniejszych obszarów $\mathrm{w}$ zakresie podejmowania inicjatyw procesowych, cieszący się coraz większym zainteresowaniem menedżerów. Istotne projekty podejmowane przez przedsiębiorstwa dotyczyły przeprojektowania procesów (38\% w 2017 roku, 36\% w 2015, $33 \%$ w 2013) oraz automatyzacji procesów (37\% w 2017 roku, $21 \%$ w 2015, 20\% w 2013).

Badania przeprowadzone w Polsce wskazują na fakt, iż w dużych przedsiębiorstwach model architektury procesów jest wykorzystywany częściej niż w grupie średnich przedsiębiorstw (Cyfert, 2006, s. 92). Modelu architektury procesów wykorzystuje się częściej w przedsiębiorstwach z udziałem kapitału zagranicznego niż w przedsiębiorstwach $\mathrm{z}$ udziałem kapitału polskiego (Cyfert, 2006, s. 91). Inne wyniki badań realizowanych w Polsce wskazują, że założenia do zarządza- nia procesowego $\mathrm{w}$ wielu przypadkach nie wynikają ze strategii, co nie jest korzystnym zjawiskiem, gdyż następuje brak integracji pomiędzy płaszczyzną strategiczną a operacyjną. Koniecznym warunkiem zastosowania zarządzania procesowego jest formułowanie celów procesów wynikających ze strategii przedsiębiorstwa oraz wyodrębnienie architektury procesów. Na związek zarządzania procesowego ze strategią wskazuje $62,7 \%$ badanych organizacji, a $34,3 \%$ wyodrębniło model architektury procesów bazujący na założeniach strategicznych (Bitkowska, 2013).

\section{Ewolucja modelu architektury procesów w przedsiębiorstwie telekomunikacyjnym}

A nalizowane przedsiębiorstwo działa od wielu lat A w sektorze telekomunikacyjnym. Wysokie osiągnięcia i stabilna pozycja na rynku są wynikiem nowoczesnych produktów i usług konwergentnych, mobilnych i stacjonarnych. W erze globalizacji przedsiębiorstwo stawia na najwyższą jakość infrastruktury oraz bogatą ofertę, wspartą przez aktywne struktury sprzedażowe. Wraz ze znacznymi zmianami zachodzącymi w sektorze telekomunikacyjnym, w zakresie rozwoju nowoczesnych technologii, sposobu realizacji różnego rodzaju usług, regulacjami prawnymi oraz wewnętrznymi przekształceniami model architektury 

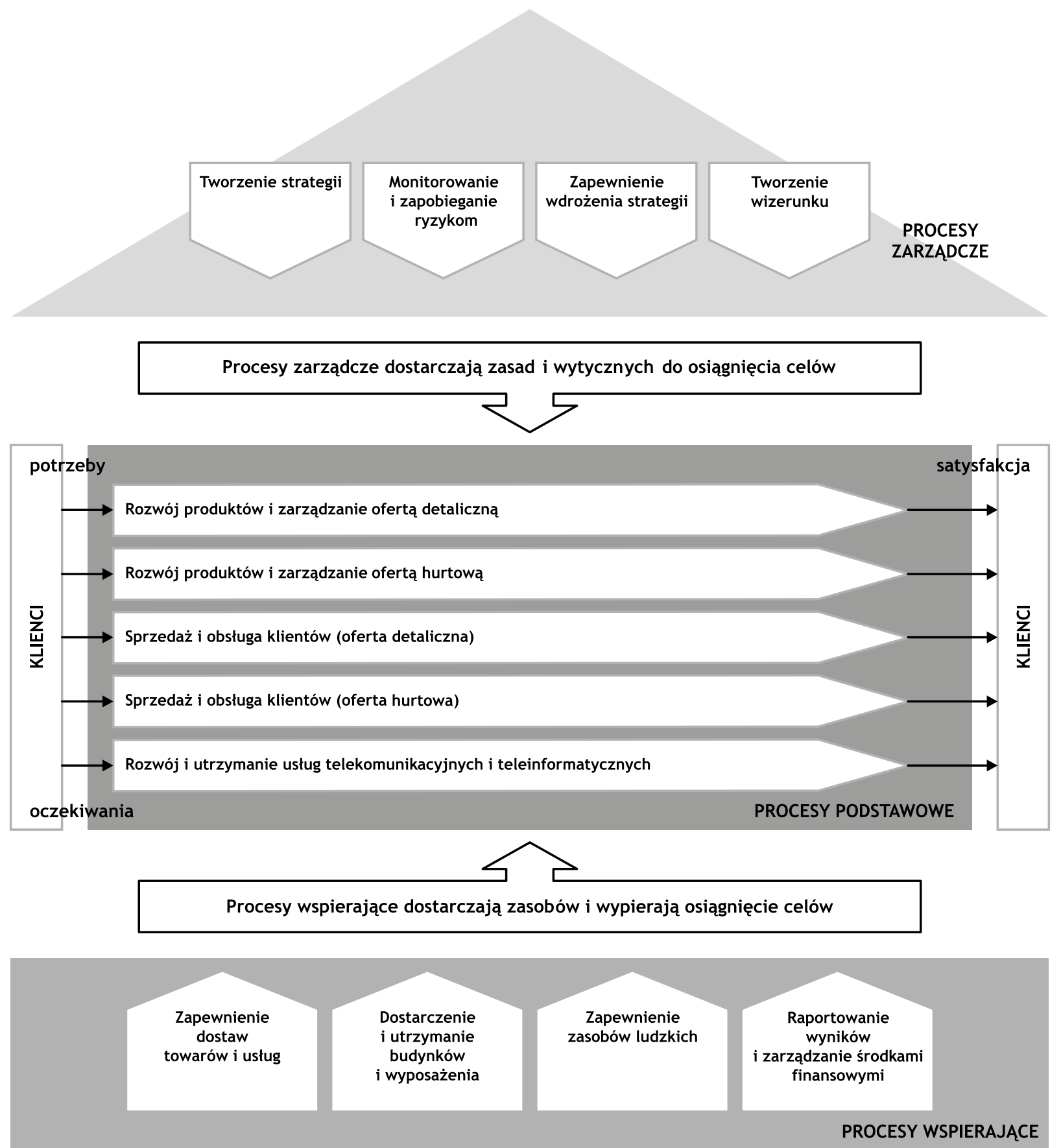

Rys. 3. Architektura procesów przedsiębiorstwa telekomunikacyjnego (poziom 1) w latach 2010-2013

Źródto: Pomykała, 2016

procesów podlegał ewolucji. Przedsiębiorstwo telekomunikacyjne musiało sprostać wielu zmianom zachodzacym $\mathrm{w}$ dynamicznym otoczeniu, gdyż rynek telekomunikacyjny w Polsce podlega regulacjom przyjmowanym na poziomie Unii Europejskiej, a następnie przenoszonym do ustawodawstwa krajowego. Ogólną zasadą stał się podział rynku telekomunikacyjnego na odrębne rynki poszczególnych usług detalicznych i hurtowych.

Najważniejsze zmiany obejmowały regulacje poprzez odpowiednie porozumienia z Urzędem Komunikacji Elektronicznej (UKE), które w znaczny sposób determinowały model funkcjonowania przedsiębiorstwa. Coraz większa konkurencja oraz szereg nowych decyzji regulacyjnych, o znaczącym wpływie na wartość całego rynku telekomunikacyjnego, spowodowały istotne decyzje strategiczne i zmiany wewnętrzne, które przebudowywały model biznesowy organizacji - model architektury procesów. Zmiana założeń strategicznych oraz uwarunkowań prawnych, nowy sposób regulacji rynku telekomunikacyjnego wymusiły konieczność dopasowania zarówno architektury procesów (poprzez identyfikację nowych procesów w łańcuchu wartości), jak też zasad zarządzania nimi (poprzez wprowadzenie ograniczeń $\mathrm{w}$ komunikacji procesowej wynikających z wdrożenia zasad Porozumienia z Urzędu Komunikacji Elektronicznej oraz poprzez zdefiniowanie nowych ról procesowych). Ewolucja modelu architektury procesów dotyczyła głównie procesów podstawowych (kluczowych), a w następnej kolejności procesów zarządczych. Procesy wspierające nie podlegały większym zmianom ze względu na brak regulacji ze strony otoczenia zewnętrznego. Proce- 

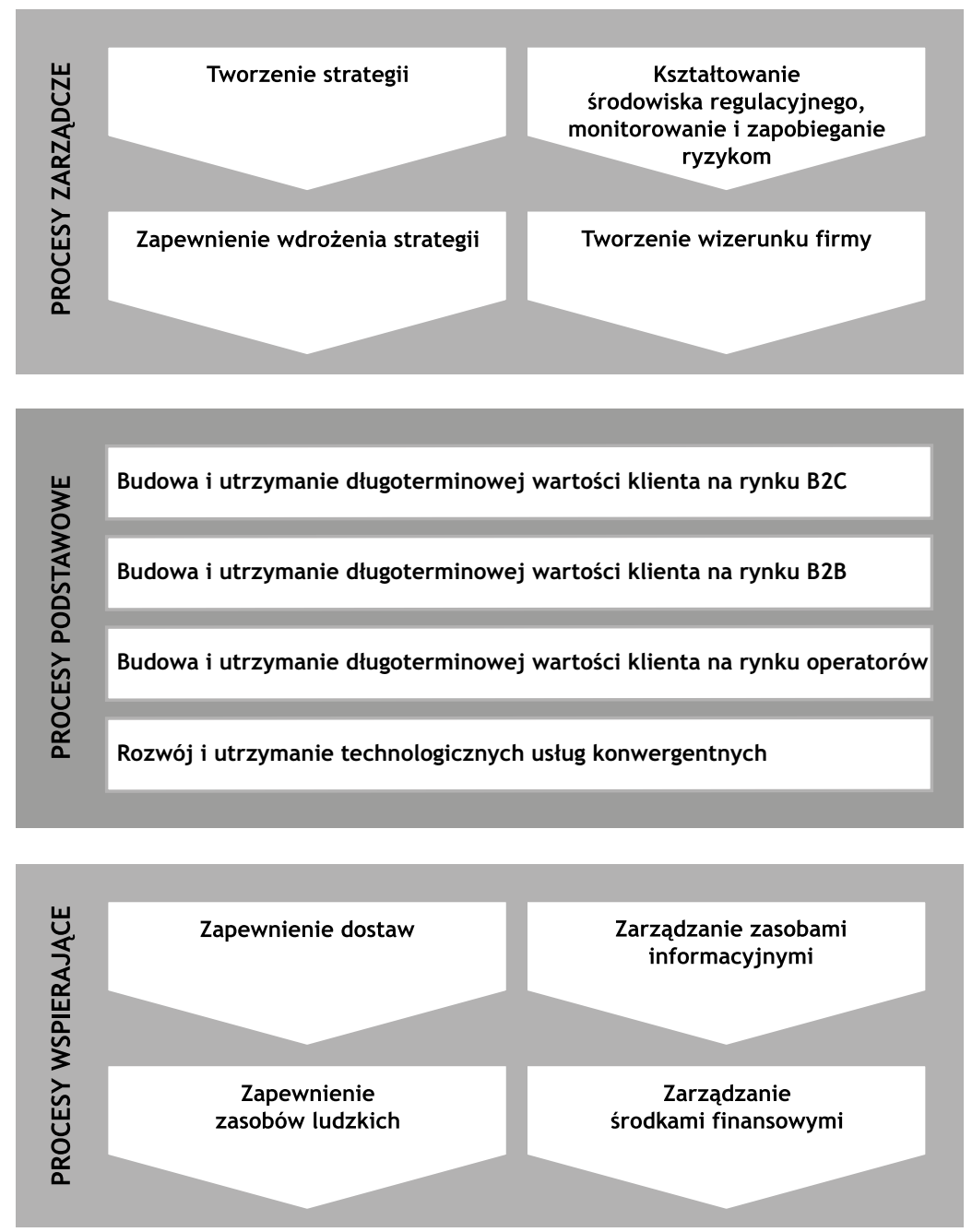

Rys. 4. Architektura procesów przedsiębiorstwa telekomunikacyjnego (poziom 1) w latach 2014-2018

Źródło: Pomykała, 2016

sy podstawowe początkowo sklasyfikowano na trzy grupy - sprzedaż i obsługa klienta, rozwój produktów i zarządzanie ofertą oraz rozwój i utrzymanie usług telekomunikacyjnych i teleinformatycznych (rys. 2). Znaczące zmiany w otoczeniu, demonopolizacja sektora telekomunikacyjnego, pojawiająca się konkurencja spowodowały zmiany w strukturze procesów podstawowych, dotyczące rozwoju produktów i zarządzania ofertą, która została rozdzielona na ofertę hurtową i detaliczną. Podobne zmiany nastąpiły w odniesieniu do procesów podstawowych dotyczących sprzedaży i obsługi klientów. Zatem kolejny model architektury procesów obejmował następujące procesy podstawowe: rozwój produktów i zarządzanie ofertą detaliczną, rozwój produktów i zarządzanie ofertą hurtową, sprzedaż i obsługa klientów (oferta detaliczna), sprzedaż i obsługa klientów (oferta hurtowa), rozwój i utrzymanie usług telekomunikacyjnych i teleinformatycznych (rys. 3). Ostatni model architektury procesów (rys. 4) w zakresie procesów podstawowych obejmował budowę i utrzymanie długoterminowej wartości klienta na różnych rynkach B2B, B2C oraz w odniesieniu do operatorów, dzięki czemu nastąpiła koncentracja na rozwoju i utrzymaniu usług konwergentnych (oferowanych łącznie wielu usług dla odbiorcy). Procesy zarządcze kon- centrowały się głównie na tworzeniu silnego wizerunku przedsiębiorstwa, realizacji strategii, zarządzaniu ryzykiem oraz podporządkowaniu działaniom regulacyjnym. Procesy pomocnicze obejmowały: zapewnienie towarów i usług, zapewnienie zasobów ludzkich, dostarczenie i utrzymanie budynków oraz wyposażenia, zapewnienie komunikacji i kompleksowe zarządzanie informacją, zarządzanie środkami finansowymi (rys. 2).

Analizując dynamizm w zaprezentowanych modelach architektury, należy podkreślić, iż największym zmianom podlegały procesy podstawowe, natomiast procesy pomocnicze i zarządcze funkcjonowały bez większych odchyleń. Zamiany zachodzące w otoczeniu, szczególnie w sektorze, w którym działa przedsiębiorstwo, najsilniej determinują funkcjonowanie procesów kierowanych do klienta zewnętrznego, przynoszące wartość dodaną. Konieczne jest definiowanie modelu architektury procesów oraz jej doskonalenie poprzez działania projektowe. Użyteczność modelu potwierdziła jego zastosowanie dla analizowanego przedsiębiorstwa poprzez zewnętrzne dostosowanie do dynamicznych zmian zachodzących na rynku, wewnętrzne uporządkowanie oraz budowanie relacji z interesariuszami. 


\section{Podsumowanie}

W yzwaniem dla współczesnych organizacji jest skuteczne wdrożenie modelu architektury procesów i dalsze jego doskonalenie. Użyteczność modelu architektury procesów jest uzasadniona, umożliwia uprządkowanie funkcjonowania procesów, zapewnia koordynację procesów oraz powiązania z założeniami strategicznymi i operacyjnymi. Architektura przedsiębiorstwa może pomóc organizacji i procesom transformacji w efektywnej realizacji strategii, ponadto działa jako instrument aktywnego planowania i sterowania, co może być zastosowane w odniesieniu do zmieniających się warunków otoczenia.

Przedsiębiorstwa w celu budowy modelu architektury procesów powinny spełnić poniższe warunki:

- zapewnienie możliwości identyfikowania i modelowania procesów zgodnie z założeniami strategicznymi,

- tworzenie hierarchiczności struktury procesów i transparentności,

- właściwe rozumienie zasad reguł budowy oraz implementacji modelu wśród kadry zarządzającej, jak też pozostałych pracowników,

- właściwe powiązanie procesów z dostępnymi zasobami,

- zapewnienie mechanizmów pomiaru i wprowadzanie zmian.

Prowadzone rozważania dotyczące wykorzystania modelu architektury procesów wskazują na pewne ograniczenia. Przeprowadzone rozważania badawcze obejmują analizę jednego przedsiębiorstwa, które silnie jest regulowane przez otoczenie zewnętrzne, instytucjonalne i prawne działające w branży telekomunikacyjnej. Kierunki dalszych prac badawczych powinny dotyczyć sposobów implementacji modelu architektury procesów, definiowania jej poziomów $\mathrm{w}$ przedsiębiorstwach $\mathrm{z}$ różnych sektorów gospodarki oraz zasięgu działania lokalnego, regionalnego czy międzynarodowego. Dalsze prace teoretyczno-empiryczne powinny obejmować wieloaspektowość analizy modelu architektury procesów i założeń jej doskonalenia.

\section{dr hab. inż. Agnieszka Bitkowska, prof. PW Politechnika Warszawska \\ Wydział Zarządzania \\ ORCID: 0000-0002-2817-8244 \\ e-mail: Agnieszka.Bitkowska@pw.edu.pl}

\section{Przypisy}

1) Architektura procesów biznesowych nie jest tożsama $z$ architekturą biznesową, która oznacza „formalny opis sposobu działania biznesowej części organizacji, na poziomie kluczowych jej składowych i relacji pomiędzy nimi” (Sobczak, 2013).

2) Wśród standardowych modeli architektur procesowych występujących w praktyce można wyróżnić (Paradkar, 2018):

- BIAN dla branży bankowej,

- ACORD Framework dla branży ubezpieczeniowej,

- eTOM dla branży telekomunikacyjnej,

- holenderska NORA lub australijska AGA dla administracji publicznej,
- NAF, DODAF i MoDAF dla obronności,

- ISA-95 i SCOR. dla produkcji i łańcuchów dostaw.

\section{Bibliografia}

[1] Aredes E.L., Dallavalle de Pádua S.I. (2014), Process Architecture as a BPM Critical Success Factor: A Bibliographic Review, „Business and Management Review”, Vol. 4, No. 3, pp. 245-255.

[2] Bitkowska A. (2013), Zarzadzanie procesowe we wspótczesnych organizacjach, Difin, Warszawa.

[3] Biazzo S., Bernardi G. (2003), Process Management Practices and Quality Systems Standards. Risks and Opportunities of the New ISO 9001 Certification, „Business Process Management Journal", Vol. 9, No. 2, pp. 149-169.

[4] Burtlon R.T. (2015), Business Architecture Essentials, https:// www.bptrends.com, access date: 15.12.2018.

[5] Burtlon R.T. (2001), Business Process Management. Profiting from Process, Sams Publishing.

[6] Brzóska J. (2009), Model biznesowy - wspótczesna forma modelu organizacyjnego, Zarządzania przedsiębiorstwem, Kwartalnik Naukowy Organizacja i Zarządzanie, Nr 2(6), s. 5-24.

[7] Ciesielska-Maciągowska D., Frąszczak M. (2017), Umiędzynarodowienie przedsiębiorstw poprzez dygitalizację, „Ekonomika i Organizacja Przedsiębiorstwa”, Nr 12, s. 68-82.

[8] Cyfert S. (2006), Strategiczne doskonalenie architektury procesów w zarządzaniu przedsiębiorstwem, Wydawnictwo Akademii Ekonomicznej w Poznaniu, Poznań.

[9] Cyfert S. (2011), Wykorzystanie koncepcji modelu biznesu $w$ projektowaniu organizacji zorientowanej na procesy, [w:] S. Nowosielski (red.), Podejście procesowe $w$ organizacjach, Wydawnictwo Uniwersytetu Ekonomicznego we Wrocławiu. Wrocław, s. 434-441.

[10] Dębska-Gil A., Woźniakowska J. (2013), Zarządzanie procesowe $w$ stużbie celnej, Wiadomości celne Nr 8, Ministerstwo Finansów - Służba Celna, Warszawa.

[11] Dijkman R., Vanderfeesten I., Reijers Hajo A. (2016), Business Process Architectures: Overview, Comparison and Framework, „Enterprise Information Systems”, Vol. 10, Iss. 2, pp. 129-158.

[12] Gołembiowski T., Dudzik T.M., Lewandowska M., Witek-Hejduk M. (2008), Modele biznesu polskich przedsiębiorstw, Szkoła Główna Handlowa, Warszawa.

[13] Harmon P. (2010), The Scope and Evolution of Business Process Management, [in:] J. vom Brocke, M. Rosemann (eds.), Handbook on Business Process Management 1, International Handbooks on Information Systems, Springer-Verlag, Berlin, Heidelberg, pp. 37-81.

[14] Harmon P. (2018), State of Business Process Management, http://www.bptrends.com, access date: 15.12.2018.

[15] Jelonek D., Turek T. (2015), Kreowanie przedsiębiorczości. Perspektywa procesów i technologii informacyjnych, Wydawnictwo Politechniki Częstochowskiej, Częstochowa.

[16] Jeston J., Nelis J. (2014), Business Process Management. Practical Guidelines to Successful Implementations, Taylor\&Francis Group, Routledge, London and New York.

[17] Kaleta A. (2000), Odwaga strategii - warunek sukcesów współczesnych przedsiębiorstw, „Przegląd Organizacji”, Nr 10, s. $8-11$. 
[18] Kaplan R.S., Norton D.P. (2010), Wdrażanie strategii dla osiagnięcia przewagi konkurencyjnej, Wyd. Naukowe PWN, Warszawa

[19] Nowosielski S. (2017a), Procesy i projekty $w$ zarządzaniu zmiana organizacyjna, Prace Naukowe Uniwersytetu Ekonomicznego we Wrocławiu, $\mathrm{Nr} 463$, s. 67-86.

[20] Nowosielski S. (2017b), Procesy a projekty $w$ organizacji, „Ekonomika i Organizacja Przedsiębiorstwa”, Nr 12, s. $140-150$.

[21] Nowosielski S. (2018), Procesy $i$ projekty $w$ organizacji. O potrzebie i sposobach współdziałania, Studia i Prace Kolegium Zarządzania i Finansów, Nr 169, s. 109-129.

[22] Obłój K. (2002), Tworzywo skutecznych strategii, PWE, Warszawa.

[23] Paradkar S. (2018), Reference Architecture \& Frameworks - A Consolidation, https://www.bptrends.com/, access date: 12.12.2018

[24] Pomykala H. (2016), Jak zapewnić użyteczność Architektury procesów do celów zarządczych, Forum Praktyków BPM.

[25] Pritchard J.P., Armistead C. (1999), Business Process Management - Lessons from European Business, „Business Process Management Journal", Vol. 5, No. 1, pp. 10-35.

[26] Rummler G.A., Brache A.P. (2000), Podnoszenie efektywności organizacji, PWE, Warszawa.

[27] Smart P.A., Maddern H., Maull R.S. (2007), Understanding Business Process Management: Implications for Theory and Practice, Working Paper Series, School of Business and Economics, University of Exeter, Exeter.
[28] Sobczak A. (2013), Architektura korporacyjna. Aspekty teoretyczne i wybrane zastosowania praktyczne, Ośrodek Studiów nad Cyfrowym Państwem.

[29] Trocki M. (red.), (2012), Nowoczesne zarządzanie projekta$m i$, PWE, Warszawa.

\section{Model of Business Process Management Architecture in Contemporary Enterprises}

\section{Summary}

The dynamics of the environment, progressive processes of globalization, and digitalization require constant improvement of methods used to build competitive advantages of contemporary enterprises. They are expressed by changes in business models of enterprises. More and more enterprises use the process architecture model, which enables linking the strategic and operational levels and achieving operational efficiency. The aim of the article is to show the utility of creating a model of process architecture in contemporary enterprises. The article uses the following research methods and techniques: literature analysis of the subject and case study. The considerations presented in the article have both cognitive and application value.

\section{Keywords}

business model, Business Process Management, Business Process Management Architectur 